\title{
Natural energy resources and their impact on environmental pollution in the transport sector in Perú
}

\section{Los recursos energéticos naturales y su impacto en la contaminación am- biental en el sector del transporte en Perú}

\author{
Erika Velásquez Chacón \\ Universidad Nacional de San Agustín de Arequipa, Perú • evelasquezcha@unsa.edu.pe \\ Efraín Jesús Molina Pinto \\ Universidad Nacional de San Agustín de Arequipa, Perú • emolina@unsa.edu.pe
}

\begin{abstract}
Natural energy resources such as natural gas are important in the development of countries that have reserves. These resources may also important in the reduction of polluting emissions generated by the vehicles of the automotive fleet. In this context, the production of natural gas fuel for vehicles allows the reduction of emissions and, consequently, of the levels of air pollution. The objective of this study is to evaluate natural energy resources and their impact on environmental pollution in the transport sector, the availability of these energy resources, the impact of pollution and the strategies for the reduction of emissions, in the Peruvian context, by reviewing information from various sources. Peru has developed projects for the production of natural gas and initiatives to distribute through a gas pipeline network. The growth of the vehicle fleet has generated high levels of air pollution in the country's cities. Natural gas vehicle fuel emits almost no heavy particles, and does not generate much PM10, and as many polluting emissions such as $\mathrm{CO} 2, \mathrm{CO}, \mathrm{NOx}, \mathrm{SO} 2, \mathrm{HC}$, generated by other fuels. There are still limitations in emission reduction strategies because the adaptation of vehicles to natural gas has decreased due to the high costs of the service and the perception of not obtaining benefits in its use, in addition to having few establishments that sell natural gas throughout the country.
\end{abstract}

Keywords: natural energy resources, environmental pollution, transport sector, emissions, natural gas.

illustro • Universidad Católica San Pablo, Arequipa • Vol. 12, 2021, 103-119 • e-ISSN 2710-2440 


\section{Resumen}

Los recursos energéticos naturales como el gas natural son importantes en el desarrollo de los países que cuentan con reservas. Dichos recursos también pueden ser importantes en la reducción de las emisiones contaminantes, generadas por los vehículos de la flota automotriz; en este marco, el desarrollo de combustibles para vehículos como el gas natural permite disminuir las emisiones y consecuentemente los niveles de contaminación en el aire. El objetivo del presente estudio es evaluar los recursos energéticos naturales y su impacto sobre la contaminación ambiental en el sector transporte, la disponibilidad de dichos recursos energéticos, el impacto de la contaminación y las estrategias para la reducción de emisiones, en el contexto peruano, mediante la revisión de información de diversas fuentes. Perú ha desarrollado proyectos para la producción de gas natural e iniciativas para distribuir a través de una red de gasoductos. El crecimiento de la flota de vehículos ha generado altos niveles de contaminación del aire en las ciudades. El gas natural vehicular es un combustible que casi no emite partículas pesadas, aparte de que no genera mucho PM10, y no genera tantas emisiones contaminantes como CO2, $\mathrm{CO}, \mathrm{NOx}, \mathrm{SO} 2, \mathrm{HC}$, que generan otros combustibles. Aún se presentan limitaciones en las estrategias para la reducción de emisiones, pues la adaptación de los vehículos al gas natural ha disminuido por los altos costos del servicio y la percepción de no obtener beneficios en el uso, además de tener pocos establecimientos que vendan gas natural en el país.

Palabras clave: recursos energéticos naturales, contaminación ambiental, sector transporte, emisiones, gas natural.

\section{Introduction}

In Peru the development of the natural gas industry was focused on the north coast of the country (1998) and used in the electricity generation of oil operations and camps. In 2004, commercial operations for natural gas began and the Camisea Project was born, generating development in the natural gas (NG) industry. NG has been increasing its share in the energy market, from $25.2 \%$ in 2018 to $25.7 \%$ in 2019 (Osinergmin, 2020). This situation is a development opportunity and is contemplated within the Sustainable Development Goals (SDG), goal 7, based on affordable and non-polluting energy, which is a challenge for the different economic sectors.

By 2050 the world will have 2,500 million more people, such a spectacular growth will result in higher energy demand and natural gas is in an ideal position to meet such needs. Compared to coal and oil, gas also ensures clean air and lower greenhouse gas emissions, thus reducing emissions (IGU, 2019). These results suggest it is important to work on the efficient use of this resource that has the potential to generate economic growth, and well-being for families and in various sectors.

On the other hand, we see that the transport sector is the one that reports the highest emissions in Peru, which is related to the average age of vehicles, their poor maintenance, consumption of polluting fuels, in addition to transportation problems related to lack of roads, traffic signals and lights, among others 
(Bernex \& Castro, 2015). The fact that «energy represents about $60 \%$ of total greenhouse gas emissions worldwide» (Porles Ochoa, 2019) suggests that it is necessary to consider energy resources as an opportunity to reduce environmental impacts, ideally with public, private and civil society participation. Air pollution is a problem that shows alarming figures. The World Health Organization (WHO) (2018) estimates that seven million people die each year due to exposure to particles contained in polluted air.

The present study contributes to evaluate energy resources and their environmental impact, recognizing availability, environmental impact and strategies for the reduction of emissions.

\section{Availability of energy resources in Peru}

\subsection{Natural gas in Peru}

Natural gas «is a gaseous fuel made up of a mixture of light hydrocarbons whose main component is methane ( $\mathrm{CH} 4)$. It is called Natural because no process is involved in its chemical constitution; it is clean, colorless and odorless» (Minem, 2009).

NG has been used as an «energy source (energy) and as a raw material in the petrochemical industry (non-energy). [...] NG is a mixture of simple hydrocarbons, in a gaseous state and composed of approximately $95 \%$ methane»; it is one of the cleanest energy sources for the environment, as it has lower levels of carbon dioxide (Osinergmin, 2017).

In Peru, energy consumption in 2019 registered an increase of $1.8 \%$ over the previous year, and, specifically in the case of natural gas consumption, was one of the fastest growing, reaching 3.7\% (Osinergmin, 2020).

Peru has natural gas reserves, both developed and undeveloped, shown in figure 2 (Osinergmin, 2020).

\subsection{Natural Gas Prospects}

World demand for energy has increased, as has the execution of investment projects to discover and exploit new oil and natural gas reserves, which allows the expansion of the reserves that currently exist in different geographical areas where there are natural energy resources (Africa, South America, Southeast Asia, Australia, Canada and the United States). From Natural Gas is obtained Compressed Natural Gas (CNG) and Liquefied 


\section{Figure 1}

Peruvian Energy Consumption Matrix

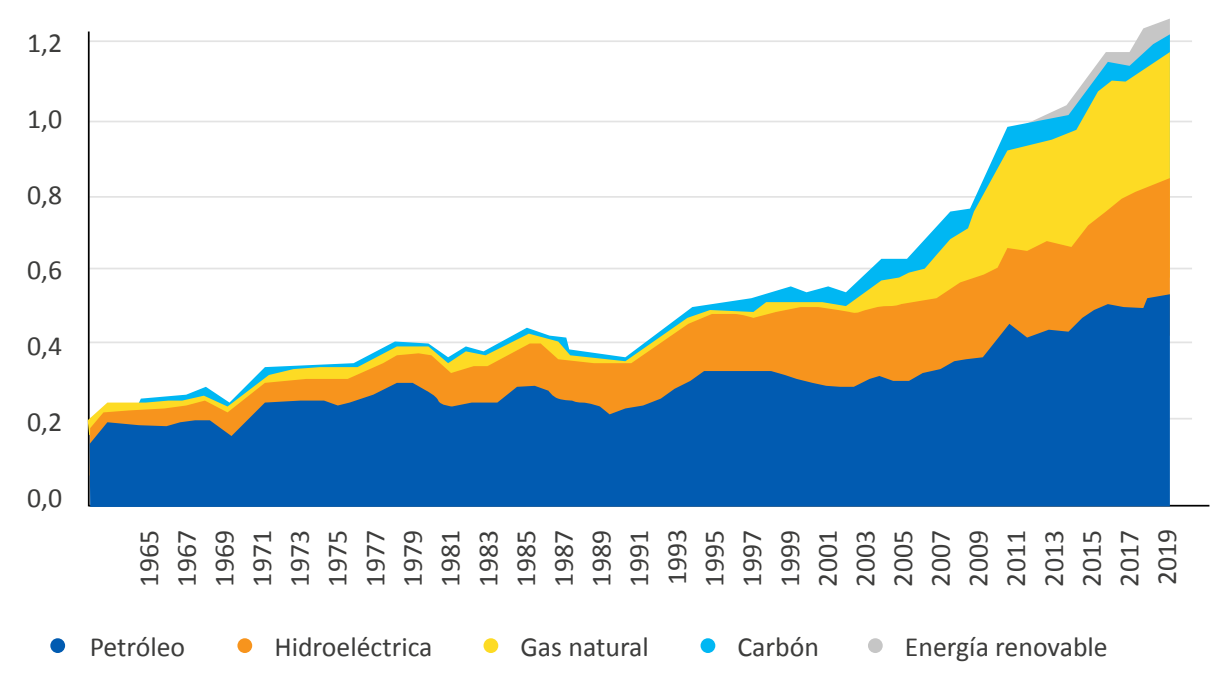

Note. Information obtained from Osinergmin (2020).

Natural Gas (LNG), from which Natural Gas for vehicles or NGV can be obtained, depending on the conditions of the land and the way in which the material is extracted (Osinergmin, 2017).

Porles Ochoa (2019) indicates that «Peru has sufficient proven reserves of natural gas to accompany an energy transition for several decades, therefore, this valuable energy resource should not be wasted». It should also be considered that natural gas is not a competitor of clean energies; on the contrary, it is an energy resource that complements wind, solar, biogas and bio-LNG.

A clear example of proven natural gas reserves is the case of Camisea production, where production has had increases «from 23\% to 95\% during the period 2004-2011 and remains, approximately, constant until 2019» (Osinergmin, 2021). Also, we cannot fail to consider development aspects and economic impacts such as:

The extraction and production of Camisea gas in Peru has generated a positive economic impact of around US\$20,000 million of net savings due to the substitution of fuels in favor of natural gas. This has undoubtedly been a key element for the efficiency of the economic and productive structure of the country, whose benefits are reflected in the residential (US\$ 773 million), commercial (US\$ 55 million), industrial (US\$ 10,291 million), vehicular (US\$ 7415 million) and electric generators (US\$ 3,081 million) sectors. (Osinergmin, 2021). 


\section{Figure 2}

Map of Approved Natural Gas Reserves by lots - December 31, 2018

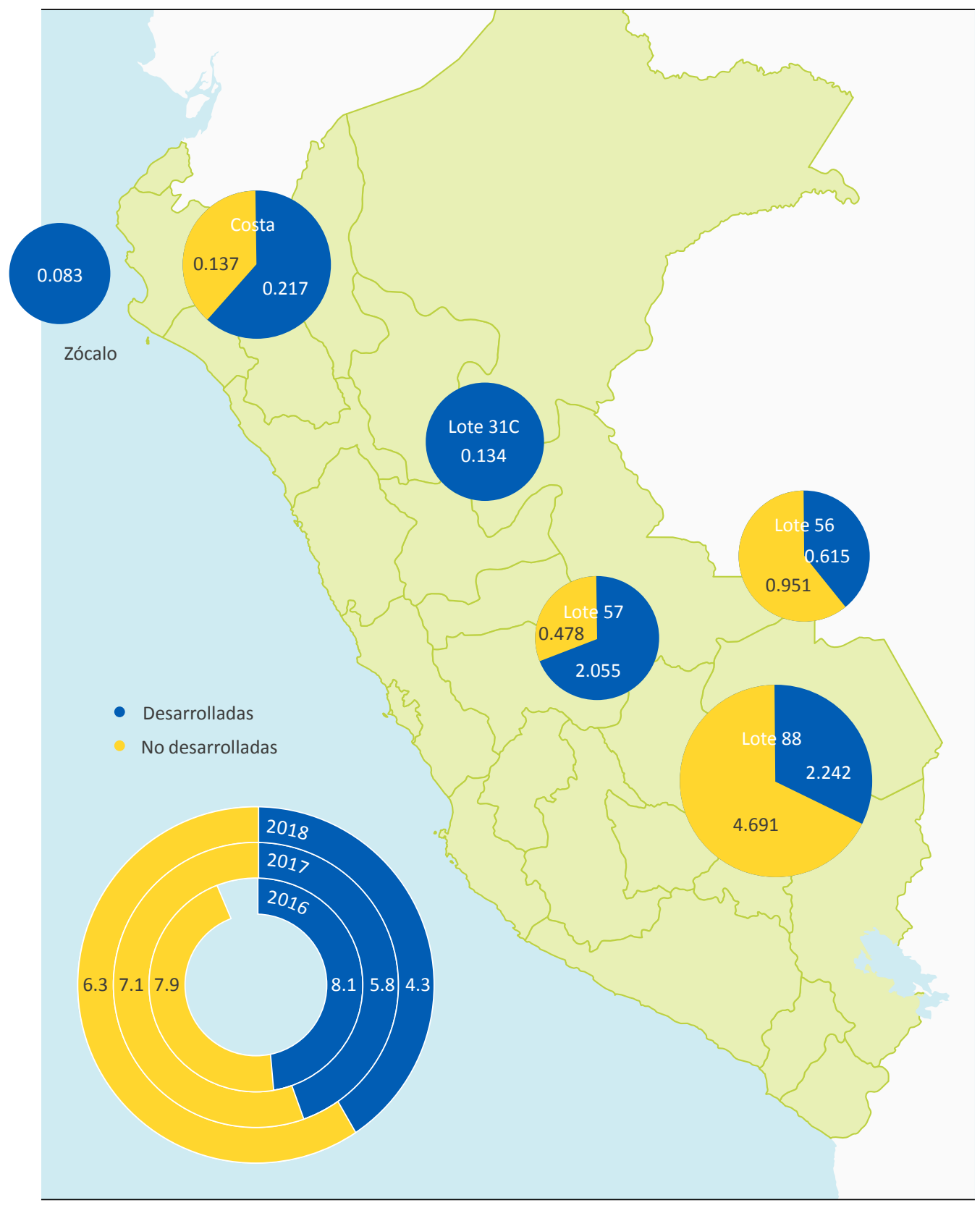

Note. Natural Gas Supervision Division DGH-Minem. Annual Book of Hydrocarbon Resources, 2018 
According to the above, it is clear that the benefits are not only economic, but also environmental, recognizing that, as IGU (2019) points out, «natural gas combined with carbon capture and storage technologies is practically a carbon-free fuel, since $90 \%$ of emissions are eliminated, and the remaining $10 \%$ could be offset with renewable gases».

\section{The environmental impact of the transport sector}

\subsection{Air quality and pollution}

Since 2005, concerns regarding the levels of environmental pollution have led the World Health Organization (WHO) to develop air quality guidelines to reduce risks related to particulate matter, ozone, nitrogen dioxide and sulphur dioxide, and to support measures aimed at achieving a degree of air quality that protects public health (WHO, 2005). The measures were necessary, but the threat of further increases in pollution levels due to non-compliance with some regulations continues to be a concern for citizens.

The main pollutants are carbon monoxide (CO), sulphur dioxide (SO2), nitrogen dioxide (NO2), ozone (O3), particulate matter less than or equal to 10 micrometers in diameter (PM10), particulate matter less than or equal

\section{Figure 3}

Photo of vehicles generating pollution

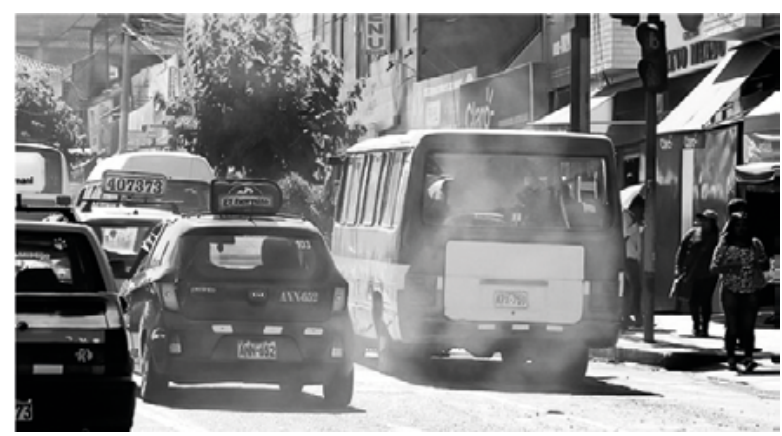

Note. Diario La República, May 29, 2019, time 19:36. https://larepublica.pe/ sociedad/1466467-pulmones-necesita-arequipa/ 
to 2.5 micrometers in diameter (PM2.5), lead $(\mathrm{Pb})$, benzene, total hydrocarbons $(\mathrm{TH})$ and hydrogen sulphide (H2S). Taking into account scientific evidence regarding air pollution and its consequences on health, and multiple toxicological and epidemiological research studies, the WHO updated the 2005 Guidelines for O3, SO2, NO2 and PM (of 10 and 2.5 microns in diameter), values that have served as the basis in the country for the update and establishment of the Environmental Quality Standards (EQS) for SO2 and PM2.5. (Minam, 2016).

In 2006, Peru issued Law 28694, that regulates the sulphur content in diesel fuel, which prohibited, starting in the year 2010, the commercialization of diesel fuel with sulphur content higher than 50 parts per million (ppm). In 2009, the Supreme Decree No. 061-2009-EM, determined the geographical areas authorized for the sale of diesel with sulphur content greater than $50 \mathrm{ppm}$ (Minem, 2009). For several years, these norms have sought to strengthen air quality in relation to pollutants generated by fuels.

Another important regulation is the Supreme Decree $\mathrm{N}^{\circ}$ 009-2012-MTC, which establishes Maximum Permissible Limits of Pollutant Emissions for Motor Vehicles (MTC, 2012). considering vehicle categories that make use of gasoline, diesel, LPG, NGV or other alternative fuels.

The increase in vehicles in the 1990s was a consequence of state policies that allowed the purchase of used vehicles, mainly dependent on diesel, which were used in public services (MINAM, 2013); many of these vehicles are still in operation today and generate high levels of contaminants. In this context, there are institutions that have been working on this issue, such as the Ministry of Environment (MINAM), the General Directorate of Health (DIGESA), the National Service of Meteorology and Hydrology of Peru (SENAMHI) and the Environmental Evaluation and Control Agency (OEFA). However, results are limited and there are still many challenges to be faced.

For Mosqueira, Fernandez \& Mosqueira (2010), the result of «comparing combustion systems using Natural Gas Vehicles (NGV), the fuel switch to Ethanol represents an increase in $\mathrm{CO} 2$ emissions»».

For Lee \& Greenstone (2021), in their report Air Quality Index points out that:

Particulate pollution levels vary widely in Latin America. In countries such as Argentina, Paraguay and Costa Rica, air quality generally meets WHO guidelines. However, other countries such as Peru, Colombia, Bolivia and Brazil have pollution hotspots, where concentrations of particulate pollutants are 2 to 3 times higher than the WHO guideline.

The same study has indicated that life expectancy in the capital city of Lima has been reduced by 4.7 years due to air pollution.

\subsection{On health effects}

In the city the main sources of pollution are vehicles and even more when there is vehicular congestion, being this the most important source of air pollutants (in particular carbon monoxide, «nitrogen oxide, unburned hydrocarbons, ozone and other photochemical oxidants, lead and, to a lesser extent, sulphur dioxide total suspended particles and volatile organic compounds» (Romero Placeres, Diego Olite, \& 
Alvarez Toste, 2006); evidently such situation has effects on the health of citizens.

Some world studies show alarming figures. Pandey et al. (2021) indicates that 67 million deaths were attributable to air pollution in India in 2019, which represents $17.8 \%$ of the total deaths in the country. Also for Zhang \& Batterman (2013), traffic congestion «increases vehicle emissions and degrades ambient air quality, and recent studies have shown excess morbidity and mortality for drivers, commuters, and people living near major roads»».

There are three factors that condition the risks of toxic injury by substances: the «physical-chemical properties, the doses of the substances that come into contact with critical tissues and the response of these to the substances») (Romero Placeres, Diego Olite, \& Alvarez Toste, 2006). Respiratory diseases are more probable where the vehicle fleet generates high levels of congestion.

Peng et al. (2021, pp. 1127-1140) point out:

China is the world's largest carbon emitter and suffers from severe air pollution, resulting in approximately one million premature deaths per year. Alternative energy vehicles (AEVs) (electric, hydrogen fuel cell, and natural gas vehicles) can reduce carbon emissions and improve air quality.

To reduce the impacts of fuels, Supreme Decree No. 007-2020-MINAM was approved, dealing with Fuel Nocivity Indexes (INC), for the period 2020-2021 (MINAM, 2020). The regulations for the implementation of this normative device are required in order to reduce the consumption of fuels that have been generating polluting emissions.
Table 1

Fuel Nocivity Indexes for the 2020-2021 period

\begin{tabular}{lc}
\hline \multicolumn{1}{c}{ Fuel type } & $\begin{array}{c}\text { Fuel Nocivity } \\
\text { Index }\end{array}$ \\
\hline Natural gas & 1.0 \\
Liquefied petroleum gas (LPG) & 2.3 \\
Anthracite coal & 6.2 \\
Bituminous coal & 9.5 \\
Gasohol 96/97/98 / octane & 10.7 \\
Gasohol 90 octane - S50 & 12.5 \\
Gasohol 90 octane & 13.1 \\
Diesel B5 - S50 & 14.2 \\
Diesel B5 - S5000 & 16.7 \\
Turbo A1 & 17.5 \\
Industrial oil No. 6 & 26.5 \\
Gasohol 84 octane - S50 & 28.9 \\
Gasohol 84 octane & 29.5 \\
\hline Industrial oil No. 500 & 36.0 \\
\hline
\end{tabular}

Note. Information obtained from S.D. 007-2020-MINAM

In the reduction of emissions, natural gas is a very important alternative source of energy.

\section{Strategies to reduce emissions}

Emissions generated by the vehicle fleet are associated with rapid population growth, increased use of public and private vehicles, and 
poor road infrastructure, and can be related to global warming, acid rain, ozone depletion (Saavedra Vargas, 2014). All of them have impacts on health but also on economic issues, and affect ecosystems. In this context, some strategies have been proposed, such as the 17 sustainable development goals, set for 2030.

\subsection{First strategy: conversion of vehicles}

Liquefied natural gas is $95 \%$ methane and 5\% ethane, propane, butane and nitrogen. It has a conversion temperature of $-161{ }^{\circ} \mathrm{C}$, when it changes from a gas to a liquid that is $1 / 600$ th of its original volume. It is odorless, colorless, anticorrosive and non-toxic. It does not contain sulphur or lead, or other heavy metals. There is a reduction of up to $97 \%$ in carbon monoxide emissions, with respect to liquid fuels. Among the disadvantages is that «a gasoline engine is not specifically designed to operate with gaseous fuels. Therefore, a decrease in engine power is presented, which may be more perceptible depending on the mechanical condition of the vehicle and the conditions of the conversion equipment» (Osinergmin, 2017). The advantages are superior to the disadvantages and contribute significantly to the protection of the environment. The Peruvian government had initiated strategies for the use of NG through NGV. However, this has stopped and this product competes in the market with some disadvantages; for example, the establishments that offer the product in the country are limited and centralized.

According to the Association of Gas and Service Stations of Peru, there were 284 establishments, of which 219 are located in Lima, 14 in Callao, 2 in Ancash, 3 in Piura, 2 in Chiclayo and 10 in Ica (Osinergmin, 2015). These add up to only 7 regions, while 18 of the 25 regions of the country are without NGV stations.
Due to the fact that the vehicles circulating throughout the country were not manufactured to make use of NGV, every vehicle needed to be adapted, which implies an additional cost for this process, which generated the opening of workshops for the conversion. It is necessary to clarify that the conversion is not only with NGV. There are two types of conversions. The vehicle can be adapted to Liquefied Particulate Gas (LPG), with which the owner could save approximately $50 \%$; and the other option is $\mathrm{NGV}$, where the savings are between $50 \%$ and $65 \%$.

In the case of automobiles, the cost is approximately US\$ 500, but in vehicles from 2005 onwards, the conversion costs rise to approximately US\$ 700. In the case of other vehicles, such as vans, the cost is higher (SITEC Inversiones S.A.C., 2020). Certainly, it may be important for companies working on vehicle technology to consider the possibility of manufacturing vehicles to make direct use of this type of fuel.

Some studies show that the conversion of vehicles is an alternative to improve air quality. In Colombia, a study on the use of LPG and NGV to determine which emits less pollutants into the atmosphere reached the conclusion that both LPG and NGV are environmentally friendly. However, the technical implementation of the conversion as well as the certification of the workshops is a weakness (Calderon Sierra \& Calderon Calderon, 2018).

Only $4 \%$ of the total exploitation of the reserves is destined to NGV. According to Osinergmin (2017), by midyear 2015 there were 203,360 cars converted to NGV. However, people no longer convert their cars to $\mathrm{NGV}$, and the construction of distribution networks stopped. By the end of 2019, although figures were positive for the 
natural gas sector, «to the extent that a region distances itself from the capital of the country, the price of natural gas through networks increases as a result of higher costs in the supply chain» (Energiminas, 2020).

A topic of great interest is the growth of the automotive fleet. As the fleet grows, so do environmental problems, mainly due to the age of the vehicles. The country with the least age in the automotive fleet is Luxembourg, with an average age of 6 years, while Brazil has 9; Chile, 10; Ecuador, 11; Argentina, 12; Peru, 14; Colombia, 15; and Mexico, also 15 (Asociación Automotriz del Perú, 2020).

On the other hand, when analyzing air quality by city (even though it has improved, going from a PM2.5 of $28 \mu \mathrm{g} / \mathrm{m}^{3}$ from 2018 to $23.7 \mu \mathrm{g} / \mathrm{m}^{3}$ in 2019) Lima is the second capital city in Latin America with the poorest air quality. The report places Santiago, Chile, in first place in the region with a PM2.5 of $27.7 \mu \mathrm{g} / \mathrm{m}^{3}$. (Automotive Association of Peru, 2020).

The information shows that although as a country Peru has improved in terms of air quality indicators, it is still reported with poor air quality, which needs to be addressed by public institutions to reduce the impacts on Peruvian society. According to the 30754 Framework Law on Climate Change and its regulations, part of the National Strategy on Climate Change, the «commitment of Peru is to incorporate the environmental approach in its public policies from concrete actions to achieve environmental performance with the highest standards and thus protect its various ecosystems» (MINAM, 2015).

\subsection{Second strategy: Energy Social Inclusion Fund (FISE)}

The Peruvian state promotes the work strategy through the Energy Social Inclusion Fund, with the purpose of massifying «the use of natural gas through partial or total financing of regulated consumers, systems or means of distribution or transportation»; it is one of the programs that strengthened the conversion to NGV. The strategy has been maintained based on Directorial Resolution No. 058-2021-Minem/DGH of March 4, 2021, and Directorial Resolution No. 117-2021-Minem/DGH of April 14, 2021, which extends its operation until December of the same year (Minem, 2021).

\subsection{Third strategy: Integrated Atmospheric Sanitation Plan (PISA)}

The Integrated Atmospheric Sanitation Plan has also been considered a strategy for the reduction of environmental pollution, where the «automotive fleet is responsible for $70 \%$ to $80 \%$ of total air pollutant emissions» 
Table 2

Vehicle fleet in circulation at the national level, by department 2008-2018

\begin{tabular}{|c|c|c|c|c|c|c|c|c|c|}
\hline Department & 2011 & 2012 & 2013 & 2014 & 2015 & 2016 & 2017 & 2018 & 2019 \\
\hline Total & $1,979,865$ & $2,137,837$ & $2,287,875$ & $2,423,696$ & $2,544,133$ & $2,661,719$ & $2,786,101$ & $2,894,327$ & $3,004,308$ \\
\hline Amazonas & 2,407 & 2,400 & 2,351 & 2,314 & 2,275 & 2,275 & 2,227 & 2,182 & 2,142 \\
\hline Áncash & 23,322 & 25,418 & 27,542 & 29,573 & 31,213 & 33,542 & 34,923 & 36,190 & 37,703 \\
\hline Apurímac & 3,966 & 4,039 & 4,083 & 4,139 & 4,192 & 4,216 & 4,177 & 4,120 & 4,048 \\
\hline Arequipa & 118,985 & 134,533 & 149,892 & 164,302 & 176,315 & 187,929 & 200,560 & 211,735 & 222,491 \\
\hline Ayacucho & 5,784 & 5,941 & 5,968 & 6,021 & 6,022 & 6,041 & 6,015 & 5,918 & 5,798 \\
\hline Cajamarca & 17,320 & 19,673 & 21,461 & 22,664 & 23,740 & 24,943 & 26,224 & 27,674 & 29,036 \\
\hline Cusco & 48,491 & 53,675 & 59,459 & 64,820 & 69,213 & 73,997 & 79,874 & 84,942 & 89,338 \\
\hline Huancavelica & 1,317 & 1,323 & 1,300 & 1,315 & 1,286 & 1,286 & 1,259 & 1,235 & 1,210 \\
\hline Huánuco & 12,576 & 13,476 & 14,261 & 14,911 & 15,648 & 16,382 & 16,915 & 17,367 & 17,991 \\
\hline Ica & 26,419 & 26,551 & 26,398 & 26,439 & 26,715 & 27,092 & 27,423 & 27,558 & 27,970 \\
\hline Junín & 53,118 & 56,237 & 59,019 & 61,933 & 64,576 & 67,049 & 69,760 & 72,316 & 74,947 \\
\hline La Libertad & 162,026 & 167,325 & 172,968 & 178,433 & 183,931 & 190,073 & 196,040 & 202,558 & 208,882 \\
\hline Lambayeque & 49,440 & 53,902 & 58,142 & 61,896 & 65,160 & 68,261 & 71,328 & 74,092 & 76,586 \\
\hline Lima-Callao & $1,287,454$ & $1,395,576$ & $1,498,037$ & $1,590,755$ & $1,674,145$ & $1,752,919$ & $1,837,347$ & $1,908,672$ & $1,982,650$ \\
\hline Loreto & 5,211 & 5,313 & 5,443 & 5,533 & 5,501 & 5,501 & 5,489 & 5,477 & 5,486 \\
\hline M.de Dios & 1,027 & 1,062 & 1,123 & 1,136 & 1,161 & 1,223 & 1,308 & 1,383 & 1,405 \\
\hline Moquegua & 14,003 & 14,608 & 14,944 & 14,979 & 14,931 & 14,931 & 14,887 & 14,810 & 14,691 \\
\hline Pasco & 7,292 & 7,238 & 7,108 & 6,956 & 6,804 & 6,804 & 6,660 & 6,545 & 6,441 \\
\hline Piura & 39,099 & 42,404 & 46,029 & 49,576 & 52,390 & 55,060 & 57,740 & 60,006 & 62,419 \\
\hline Puno & 37,074 & 40,543 & 43,477 & 45,056 & 46,200 & 47,696 & 49,387 & 51,041 & 52,689 \\
\hline San Martín & 10,418 & 10,926 & 11,271 & 11,648 & 12,047 & 12,358 & 12,669 & 13,052 & 13,491 \\
\hline Tacna & 42,318 & 44,430 & 45,960 & 47,180 & 48,201 & 49,382 & 50,858 & 52,161 & 53,271 \\
\hline Tumbes & 3,119 & 3,257 & 3,320 & 3,372 & 3,415 & 3,451 & 3,423 & 3,375 & 3,313 \\
\hline Ucayali & 7,679 & 7,987 & 8,319 & 8,745 & 9,052 & 9,310 & 9,608 & 9,918 & 10,310 \\
\hline
\end{tabular}

Note. Information reported by the National Institute of Statistics and Informatics of 2019 using the Ministry of Transportation and Communications as source. 
(MINAM, 2016). Other strategies are being developed in relation to the evolution of the vehicle fleet so that, based on technology, emissions can be reduced; this is the case of the EURO IV vehicle, which can reduce emissions by up to half (MINAM, 2016), as shown in figure 5.

Table 3

Emission reductions when moving from Euro III to Euro IV

\begin{tabular}{lccc}
\hline \multicolumn{1}{c}{ Air pollutants } & EURO IV & EURO III & Emissions reduction \\
\hline Carbon monoxide CO $(\mathrm{g} / \mathrm{km})$ & 0.50 & 0.64 & $22 \%$ \\
Nitrogen oxides NOx $(\mathrm{g} / \mathrm{km})$ & 0.25 & 0.50 & $50 \%$ \\
Hydrocarbons + NOx $(\mathrm{g} / \mathrm{km})$ & 0.30 & 0.56 & $46 \%$ \\
Particulate material PM $(\mathrm{g} / \mathrm{km})$ & 0.025 & 0.05 & $50 \%$ \\
\hline
\end{tabular}

Note. Information obtained from D.S. 009-2012-MINAM.Communications as source.

\subsection{Fourth strategy: massification of natural gas}

Another important strategy is the massification of natural gas. Porles Ochoa (2019) points out that the massification of gas can generate a contribution in the reduction of $\mathrm{CO} 2$ emissions, but «massification has not achieved a considerable expansion in the local market (internal) except for the electricity market, where distributed natural gas reached in 2016 a $71.5 \%$ share».

Some studies have considered that the use of natural gas requires a considerable gas production, infrastructure for gas trade and an increase in production for future utilization (Hagos \& Ahlgren, 2018). Peru meets the first condition, but requires the improvement of infrastructure to increase production and strengthen the sector.

\subsection{Fifth strategy: promotion of vehicle scrappage}

Some incentives related to vehicle scrapping are being worked on. This initiative was born with the Supreme Decree 005-2021-MTC dated February 5, 2021 (MTC, 2021). The initiative aims to Article 1:

Promote the definitive removal or renewal of vehicles from the vehicle fleet, in order to reduce greenhouse gas (GHG) emissions and local pollutants that affect public health, as well as, contribute to reduce the accident rate on public roads and improve the land transportation system. 
This consists of scrapping, dismantling and physically disintegrating a vehicle and its components, for the protection of the environment and public health.

\subsection{Sixth strategy: sectoral policy actions on emissions and SDGs}

The participation of the state is necessary to strengthen the use of natural gas, mainly in the transport sector, which generates high levels of emissions. This would allow meeting the commitments made with the 2030 Agenda and the SDGs.

The National Strategy for Climate Change was born as a comprehensive management tool to address this situation. Peru has made commitments regarding adaptation to climate change and the reduction of emissions of greenhouse gases (GHG). The National Strategy for Climate Change is an instrument to improve environmental conditions and Peru, committed to this strategy, must strengthen the institutional framework of government agencies such as the Ministry of Environment (MINAM), the General Directorate of Health (DIGESA), the National Service of Meteorology and Hydrology of Peru (SENAMHI), the Ministry of Energy and Mines (Minem) and the Environmental Evaluation and Control Agency (OEFA).

According to the National Plan proposed from 2014 to 2025 by the Ministry of Energy and Mines, it was estimated for 2025 that Greenhouse Gas (GHG) emissions «generated by the final consumption of energy in the different sectors, would fluctuate between 81 thousand and 92 thousand Giga Gram of carbon dioxide equivalent ( $\mathrm{Gg}$ of $\mathrm{CO} 2 \mathrm{eq}$ ), lower values between $15 \%$ and $10 \%$, respectively»
(Minem, 2014). However, the support of the public sector in investment must be considered to achieve the expansion in the exploitation of natural gas, massification and efficiency at the vehicle level, among others.

\subsection{Other aspects to consider}

During the Covid-19 pandemic and quarantine periods worldwide, contamination levels were reduced. There is evidence of «a decrease in the variation of the average NO2 concentration $\left(\mu \mathrm{g} / \mathrm{m}^{3}\right)$ and diesel demand (thousands of barrels/day) in the months of March, April and May of the period 2019-2020» (Chavez Flores, 2020). The end of the pandemic may lead to maintain some forms of remote work, with significant changes from the pre-pandemic reality.

\section{Findings}

Peru has developed and undeveloped natural gas reserves. The demand for this source of energy has had an important increase in recent years; the Camisea Project has registered increases in production from $23 \%$ to $95 \%$ between 2004 and 2011, and has remained relatively constant until 2019, a situation that has generated positive economic impacts, with net saving of US\$ 7,415 million in the vehicle sector and improvements in environmental quality.

The transport sector generates high levels of pollution. Countries such as Peru, Colombia, Bolivia and Brazil have pollution hotspots where the concentration of particulate pollutants are 2 to 3 times higher than WHO guidelines; in the case of Peru, life expectancy in the capital of the country has been reduced by 4.7 years due to air pollution. 
Strategies to improve air quality include the conversion of vehicles for the use of natural gas, and the Energy Social Inclusion Fund (FISE) for the massification of the use of natural gas and to strengthen the processes of conversion to NGV. A third strategy is the Atmospheric Sanitation Plan (PISA) that has been working to reduce environmental pollution, based on technology access to vehicles with high standards for reducing emissions, massification of natural gas for the environmental contributions generated. Another strategy is the promotion of scrapping to remove used vehicles that generate high levels of emissions. Sectoral policy measures on emissions and the commitment to the Sustainable Development Goals may lead to a reduction in greenhouse gases and consequently improve environmental conditions, if the institutional framework is strengthened.

\section{Conclusions}

Peru has many proven reserves of natural gas for the energy transition; the massification of natural gas can generate greater benefits in terms of efficiency and productivity. Given increases in energy demand, the discovery and exploitation of new reserves is an opportunity, as has been demonstrated by the positive economic impacts generated by the Camisea Project (Osinergmin, 2021) and the environmental benefits generated by significantly reducing emissions (IGU, 2019).

Regulatory frameworks have been developed to reduce pollution levels; these norms have sought that for several years to improve air quality. However, the results are limited. For Peru the increase of the vehicle fleet generates a great pressure on air quality. Studies in Peru show that life expectancy in Lima has been reduced by 4.7 years due to air pollution (Lee \& Greenstone, 2021). In this context, the use of natural gas vehicles is an important strategy in the reduction of air pollution (Peng et al., 2021; Pandey et. al., 2021; Zhang \& Batterman, 2013; Romero Placeres et al., 2006).

The main actor in the reduction of greenhouse gas $(\mathrm{GHG})$ emissions is the transport sector; however, strategies are being developed to reduce the impacts, including vehicle conversion, the Social Inclusion Energy Fund (FISE), the Integrated Atmospheric Sanitation Plan (PISA), the massification of natural gas, sectoral policy measures on emissions and commitment to the SDGs, and the promotion of vehicle scrappage. However, it is necessary to strengthen the institutional framework. 
Bernex, N., \& Castro, A. (2015). Rio+20 Desafios y perspectivas. http://repositorio.pucp.edu.pe/index/ bitstream/handle/123456789/173170/R\%C3\%ADo\%2020.\%20Desaf\%C3\%ADos\%20y\%20perspectivas. pdf?sequence $=1 \&$ isAllowed=y\#page $=167$

Calderón Sierra, M., \& Calderón Calderón, E. Y. (2018). Análisis ambiental comparativo del uso del gas licuado del petróleo (GLP), como combustible sustituto del gas natural vehicular (GNV) en Colombia. [Tesis de Pregrado. Universidad Industrial de Santander]. http://tangara.uis.edu.co/biblioweb/ tesis/2018/172349.pdf

Chávez Flores, E. (2020). Incidencia de la cuarentena por covid-19, en la calidad del aire (NO2) de la ciudad de Lima. Revista del Instituto de Investigación de la Facultad de Ingeniería Geológica, Minera, Metalúrgia y Geográfica. https://revistasinvestigacion.unmsm.edu.pe/index.php/iigeo/article/view/18183

Congreso de la República del Perú (2018). Ley № 30754 Ley Marco sobre Cambio Climático. https://busquedas. elperuano.pe/normaslegales/ley-marco-sobre-cambio-climatico-ley-n-30754-1638161-1/

Hagos, D. A., \& Ahlgren, E. O. (2018). Well-to-wheel assessment of natural gas vehicles and their fuel supply infrastructures - Perspectives on gas in transport in Denmark. Transportation Research Part D: Transport and Environment, 65, 14-35. doi:10.1016/j.trd.2018.07.018

IGU (2019). Sustainable Future Powered by Gas. Global Natural Gas Insights. https://www.igu.org/wp-content/ uploads/2020/06/IGU-2019_web_spreads-min.pdf

INEI (20 de diciembre de 2019). Transporte, almacenamiento, correo y mensajería. https://www.inei.gob.pe/ estadisticas/indice-tematico/prueba-11103/

Lee, K., \& Greenstone, M. (2021). Annual Update. Air Quality Life Index. https://aqli.epic.uchicago.edu/ wp-content/uploads/2021/08/AQLI_2021-Report.EnglishGlobal.pdf

Mardones, C., \& Jorge, F. (2017). Regulaciones para reducir emisiones de MP 2.5 y externalidades sobre sus precursores cuando existe disponibilidad de un combustible limpio. Revista internacional de contaminación ambiental. http://www.scielo.org.mx/scielo.php?script=sci_arttext\&pid=S0188-49992017000300505\#t1

MINAM (2013). Estudio de Desempeño Ambiental 2003-2013. https://www.minam.gob.pe/esda/parte-doscapitulo-6-aire/

MINAM (2015). Estrategia Nacional ante el Cambio Climático. https://www.minam.gob.pe/wp-content/ uploads/2015/09/ENCC-FINAL-250915-web.pdf

MINAM (2016). Informe Nacional de la Calidad del Aire 2013-2014. https://www.minam.gob.pe/wp-content/ uploads/2016/07/Informe-Nacional-de-Calidad-del-Aire-2013-2014.pdf

MINAM (2016). Preguntas y Respuestas para entender el caso del Euro IV. https://www.minam.gob.pe/ wp-content/uploads/2016/07/preguntas-y-respuestas-Euro-IV-15-07-2016Revisi\%C3\%B3n-Ministro-5pmcopia.pdf

MINAM (2020). Decreto Supremo 007-2020-MINAM. https://busquedas.elperuano.pe/download/url/apruebanindices-de-nocividad-de-combustibles-inc-para-el-decreto-supremo-n-007-2020-minam-1878038-1

Minem (2009). Decreto Supremo N061-2009-EM. https://www.osinergmin.gob.pe/seccion/centro_documental/ PlantillaMarcoLegalBusqueda/Criterios\%20para\%20determinar\%20zonas\%20geograficas\%20donde\%20 
se\%20podra\%20autorizar\%20el\%20expendio\%20de\%20Diesel\%20con\%20azufre\%20mayor\%20a\%2050\%20ppm.pdf

Minem (2009). Usos y ventajas del gas natural en el sector residencial - comercial. http://www.minem.gob.pe/ minem/archivos/GAS\%20NATURAL\%20EN\%20EL\%20SECTOR\%20RESID-COMERCIAL\%20_JUNIO\%2009_.pdf

Minem (2014). Plan Energético Nacional 2014-2025. http://www.minem.gob.pe/minem/archivos/file/ institucional/publicaciones/InformePlanEnerg\%C3\%ADa2025-\%20281114.pdf

Minem (2021). Resolución Directoral N058-2021-Minem/DGH. http://www.fise.gob.pe/pags/Transparencia_Fise/ Transferencias_CE/Programa\%20de\%20Transferencia\%20FISE\%20GNV\%20N\%C2\%B0\%2001-2021\%20 (enero).pdf

Mosqueira A., Fernandez Henao, S., \& Mosqueira M., J. C. (2010). Análisis de emisiones de CO2 para diferentes combustibles en la población de taxis en Pereira y Dosquebradas. Scientia Et Technica, pp. 141-146. https:// www.redalyc.org/pdf/849/84917249025.pdf

MTC (2012). Decreto Supremo 009-2012-MTC. https://www.minam.gob.pe/wp-content/uploads/2013/09/ds_0092012-minam.pdf

MTC (2021). Decreto Supremo que aprueba el Reglamento Nacional para el Fomento del Chatarreo. https:// elperuano.pe/NormasElperuano/2021/02/28/1931252-1/1931252-1.htm

OMS (2005). Guías de calidad del aire de la OMS relativas al material particulado, el ozono, el dióxido de nitrógeno y el dióxido de azufre. http://apps.who.int/iris/bitstream/handle/10665/69478/WHO_SDE_PHE_ OEH_06.02_spa.pdf;jsessionid=AABA9F24C1A346FB4ABC44C8A3DD7B13?sequence $=1$

OMS (2 de mayo de 2018). Nueve de cada diez personas de todo el mundo respiran aire contaminado. https:// www.who.int/es/news/item/02-05-2018-9-out-of-10-people-worldwide-breathe-polluted-air-but-morecountries-are-taking-action

Osinergmin (2008). Operación de plantas de procesamiento de gas natural. http://gasnatural.osinerg.gob.pe/ contenidos/uploads/GFGN/Operacion_Plantas_Procesamiento_de_Gas_Natural.pdf

Osinergmin (2015). Establecimientos de venta al público de GNV en operación. http://gasnatural.osinerg.gob.pe/ contenidos/uploads/GFGN/En_operacion.pdf

Osinergmin (2017). La industria del gas natural en el Perú a diez años del proyecto Camisea. https://www. osinergmin.gob.pe/seccion/centro_documental/Institucional/Estudios_Economicos/Libros/Libro-IndustriaGas-Natural-Peru-10anios-Camisea.pdf

Osinergmin (2020). Boletín estadístico - Procesamiento, producción y transporte de Gas Natural. http://gasnatural. osinerg.gob.pe/contenidos/uploads/GFGN/Osinergmin-boletin-estadistico-gas-natural-2020-III.pdf

Osinergmin (2021). La industria del Gas Natural en el Perú - Mirando al bicentenario y perspectivas recientes. https://www.osinergmin.gob.pe/seccion/centro_documental/Institucional/Estudios_Economicos/Libros/ Libro-Industria-Gas-Natural-Peru-bicentenario.pdf 
Peng, L., Liu, F., Zhou, M., Li, M., Zhang, Q., \& Mauzerall, D. L. (2021). Alternative-energy-vehicles deployment delivers climate, air quality, and health co-benefits when coupled with decarbonizing power generation in China. One Earth, pp. 1127-1140. https://www.sciencedirect.com/science/article/pii/S2590332221004085

Porles Ochoa, F. D. (2019). ¿Es realmente aprovechado el gas natural en el Perú? Estudio de su utilización y competitividad. enerLAC, III(2). http://enerlac.olade.org/index.php/ENERLAC/article/view/89/73

Pandey, A., Brauer, M., Cropper, M. L., Balakrishnan, K., Mathur, P., Dey, S., ... Beig, G. (2021). Health and economic impact of air pollution in the states of India: the Global Burden of Disease Study 2019. The Lancet Planetary Health, 5(1), e25-e38. doi:10.1016/s2542-5196(20)30298-9

Romero Placeres, M., Diego Olite, F., \& Alvarez Toste, M. (2006). La contaminación del aire: su repercusión como problema de salud. Revista Cubana de Higiene y Epidemiología. http://scielo.sld.cu/scielo.php?script=sci_ arttext\&pid=s1561-30032006000200008

Saavedra Vargas, J. D. (2014). Análisis de nuevos escenarios de emisión de contaminantes del parque automotor generados en un ambiente de tráfico vehicular [Tesis de Pregrado. Universidad Nacional Agraria La Molina]. http://repositorio.lamolina.edu.pe/handle/20.500.12996/1872

SITEC Inversiones S.A.C. (10 de agosto de 2020). ¿Cuál es el precio de la conversión a GLP o GNV en Lima 2020? SITEC Inversiones S.A.C. https://www.sitec.pe/precio-conversion-glp-gnv-lima/

Zhang, K., \& Batterman, S. (2013). Air pollution and health risks due to vehicle traffic. Science of The Total Environment, 450-451, 307-316. doi:10.1016/j.scitotenv.2013.01.0

Fecha de recepción: 6 de octubre de 2021 Fecha de aceptación: 2 de diciembre de 2021 